\title{
Sertifikasi Pendidik dan Profesionalitas Guru SD Negeri Balirejo Yogyakarta: Antara Legalitas dan Realitas
}

\author{
Sri Erdawati ${ }^{1}$, Arivaie Rahman ${ }^{2}$, Masriani ${ }^{3}$ \\ ${ }^{1}$ Pendidikan Guru Madrasah Ibtidaiyah, STAI Auliaurrasyidin, Tembilahan, Indonesia \\ ${ }^{2}$ Manajemen Bisnis Syariah, STIT Al-Kifayah Riau, Pekanbaru, Indonesia \\ ${ }^{3}$ Pendidikan Guru Madrasah Ibtidaiyah, STAI Auliaurrasyidin, Tembilahan, Indonesia \\ *Corresponding author: srierdawati9@ gmail.com \\ *Corresponding author: arivai.rahman@yahoo.com \\ *Corresponding author: riani.muhammadsyah@gmail.com
}

\begin{abstract}
Abstrak
Penelitian ini dilakukan untuk melihat dan membuktikan, sejauh mana guru bersertifikasi di SD Negeri Balirejo Yogyakarta merealisasikan keprofesionalannya. Sebab, ketika pemerintah telah menjamin mutu guru yang lulus sertifikasi sebagai guru profesional yang telah teruji kompetensinya serta terpenuhi hak-haknya, maka guru dituntut bekerja maksimal dan profesional demi meningkatkan mutu pendidikan Nasional. Peneliti juga membandingkannya, dengan kualitas guru-guru non-sertifikasi di sekolah yang sama. Penelitian kualitatif ini menjadikan seluruh guru SD Negeri Balirejo Yogyakarta yang berjumlah 9 orang, sebagai subjek penelitian. Teknik pengumpulan data dalam penelitian ini, menggunakan Metode Triangulasi (observasi, wawancara, dan dokumentasi). Teknik deskriptif-analisis, digunakan untuk mengulas dan menganasis data temuan. Hasil penelitian yang diperoleh adalah, bahwa tingkat pencapaian implementasi keprofesionalan guru-guru bersertifikasi masih rendah. Legalitas sertifikasi pendidik, tidak menjamin terciptanya guru profesional. Sebaliknya, kompetensi guru non-sertifikasi belum tentu tidak profesional, realita di lapangan menunjukkan bahwa guru non-sertifikasi sudah ada yang dapat dinilai sebagai guru ideal dan profesional. Untuk menuntaskan problem ini penulis memberikan beberapa rekomendasi: 1). Reinforcement, 2). Reorientasi tujuan, 3). Monitoring dan evaluasi, 4). Self kontrol dan Self correction, 5). Kontrol social, dan 6). Konstribusi.
\end{abstract}

Kata Kunci: Profesionalitas Guru, Sertifikasi Pendidik.

\section{PENDAHULUAN}

Salah satu perjuangan yang senantiasa harus terus dilakukan oleh bangsa Indonesia adalah, perjuangan untuk mencerdaskan kehidupan bangsa. Dengan bekal kecerdasan, bangsa Indonesia akan sanggup mengisi kemerdakaan dan melakukan pembangunan disegala bidang, terutama bidang politik, ekonomi, dan sosial. Tujuan akhir yang ingin dicapai adalah agar masyarakat adil, makmur, dan sejahtera sebagaimana yang dicita-citakan oleh para pendiri bangsa dan terangkum dalam Pancasila.

Undang-Undang Republik Indonesia tahun 2005 juga menyebutkan bahwa: pembangunan nasional dalam bidang pendidikan adalah upaya mencerdaskan kehidupan manusia Indonesia yang beriman, bertakwa dan berakhlak mulia serta menguasai ilmu 
pengetahuan, teknologi dan seni dalam mewujudkan masyarakat yang maju, adil, makmur dan beradab berdasarkan Pancasila dan Undang-Undang. ${ }^{1}$

Satu-satunya upaya yang harus ditempuh, untuk mencerdaskan kehidupan bangsa tersebut adalah melalui jalur pendidikan. Perbicangan tentang dunia pendidikan adalah sebuah tema yang menarik, dan merupakan isu sepanjang masa. Pendidikan adalah proses dimana generasi muda, dipersiapkan untuk memasuki masa depan. Jika persiapannya tidak matang dan salah arah, maka output yang dihasilkan tidak akan mampu menjalankan tugas-tugasnya di masa depan sesuai dengan yang diharapkan. Riant Nugroho mengatakan "Education is the passport for the future, and the future is (also) now" (Pendidikan adalah kunci untuk masa depan, dan masa depan itu adalah sekarang). ${ }^{2}$

Saat ini setidaknya terdapat tiga persoalan sentral yang menjadi isu strategis pendidikan nasional, sebagaimana yang disebutkan oleh Yahya Muhaimin (2002), bahwa tiga masalah pendidikan di Indonesia tersebut adalah soal pemerataan, mutu dan manajemen. ${ }^{3}$ Lebih jauh Riant Nugroho (2008) menguraikan tiga masalah pendidikan itu adalah pemerataan pendidikan yang belum proposional, lemahnya manajemen pendidikan (termasuk kebijakan pendidikan, efisiensi pendidikan, pembiayaan) dan rendahnya mutu pendidikan (termasuk di dalamnya perkembangan anak, guru, relevansi). ${ }^{4}$

Rendahnya mutu pendidikan, tidak dapat dipisahkan dari keberadaan guru dan pendidik. Karena dalam ruang lingkup yang lebih kecil (mikro), pendidikan bisa terjadi setelah ada interaksi antara guru (pendidik) dengan peserta didik (murid) dalam situasi pendidikan. Pendidikan yang baik dan bermutu salah satunya ditentukan dengan adanya guru yang bermutu, sejahtera dan terlindungi. Untuk menjadi guru yang bermutu tidaklah mudah, diperlukan kerja keras dan tentu melalui banyak hambatan.

Menanggapi dan menindaklanjuti masalah tersebut, pemerintah tidak tinggal diam. Upaya peningkatan kualitas mutu pendidikan, dari tahun ke tahun selalu menjadi program dan prioritas pemerintah. Salah satunya adalah dengan ditetapkannya UndangUndang Nomor 20 tahun 2003 tentang Sistem Pendidikan Nasional, hingga sampai dilanjutkan dengan Peraturan Menteri Pendidikan Nasional Nomor 16 tahun 2007 tentang Standar Kualifikasi dan Kompetensi Guru, dan juga Peraturan Pemerintah Nomor 74 tahun 2008 tentang Dosen.

Kualifikasi pendidikan ditentukan oleh penyempurnaan integral dari seluruh komponen pendidikan, salah satunya adalah kualifikasi guru. Oleh sebab itu, profesionalisme guru merupakan suatu keniscayaan mutlak. Menghadapi berbagai tantangan dalam reformasi pendidikan nasional, diperlukan kualitas guru yang mampu mewujudkan kinerja profesional, modern, dalam nuansa pendidikan dengan dukungan

\footnotetext{
${ }^{1}$ Undang-undang Republik Indonesia, Nomor 14 tahun 2005, hlm. 1.

${ }^{2}$ Riant Nugroho, Pendidikan Indonesia: Harapan, visi dan strategi, (Yogyakarta: Pustaka Pelajar, 2008), hlm. 9.

${ }^{3}$ Yahya Muhaimin, Reformasi Pendidikan dalam Konteks Otonomi Daerah, Faisal Jalal dan Dede Supriadi (ed.), (Yogyakarta: Depdiknas, Bapenas dan Adicita Karya Nusa, 2002), hlm. xxxi.

${ }^{4}$ Riant Nugroho, Pendidikan Indonesia: Harapan, hlm. 13.
} 
kesejahteraan yang memadai dan berada dalam lindungan kepastian hukum.

Dalam Undang-Undang Guru dan Dosen pasal 1 ayat 1 dinyatakan bahwa: "Guru adalah pendidik profesional dengan tugas utama mendidik, mengajar, membimbing, mengarahkan, melatih, menilai dan mengevaluasi peserta didik pada pendidikan anak usia dini jalur pendidikan formal, pendidikan dasar, dan pendidikan menengah". ${ }^{5}$ Karakter guru profesional akan tercermin dari penampilan pelaksanaan pengabdian tugas-tugas yang ditandai dengan keahlian, baik dalam materi, metode, tanggungjawab pribadi, sosial, intelektual, moral dan spiritual, serta kesejawatan (rasa kebersamaan diantara sesama guru).

Mematuhi amanat Undang-Undang Sistem Pendidikan Nasional Nomor 20 tahun 2003, pemerintah terus berupaya untuk meningkatkan mutu pendidikan. Upaya ini ditandai dengan merekonstruksi kebijakan lama dan membangun konsep kebijakan baru meningkatkan profesionalisme guru dengan melakukan sertifikasi. ${ }^{6}$ Melalui sertifikasi, guru dituntut menjadi sosok guru profesional yang diukur dengan beberapa syarat yang harus dipenuhi termasuk penguasaan terhadap standar kompetensi tertentu (pedagogik, kepribadian, profesional dan sosial), serta diukur dengan skor nilai tertentu.

Apakah dengan adanya sertifikasi menunjukkan fakta bawha kualitas guru-guru di Indonesia selama ini masih rendah? Memang ini sebuah kenyataan yang tidak dapat dipungkiri. Hasil survey tentang kondisi kualitas Sumber Daya Manusia (SDM) Indonesia sangat memprihatinkan. Misalnya, menurut laporan UNDP (United Nations Development Programme), bahwa Indeks pembangunan manusia Indonesia (HDI / Human Development Index) masih berada pada rangking 111 dari 177 Negara anggota PBB. $^{7}$

Berdasarkan uraian latar belakang di atas, tema tentang sertifikasi dan profesionalitas guru ini sangat menarik untuk dikembangkan mejadi suatu penelitian. Sebab ketika pemerintah telah menjamin mutu guru yang lulus sertifikasi sebagai guru profesional yang teruji kompetensinya dan telah terpenuhi hak-haknya, maka guru harus bekerja maksimal secara profesional demi terwujudnya peningkatan mutu pendidikan.

Penelitian yang diangkat dalam tulisan ini fokus pada guru SD Negeri Balirejo Yogyakarta yang sudah lulus sertifikasi, dan membandingkannya dengan guru yang non-sertifikasi. Penelitian ini ingin melihat realita profesionalitas guru-guru bersertifikasi yang secara teoritis ketika telah menerima sertifikat dan tunjangan profesi, tentu mutu dan kualitasnya akan menjadi lebih baik dan meningkat. Selain itu, tujuan penelitian ini juga untuk mengetahui dan membuktikan apakah legalitas sertifikasi sejalan dengan realitas di lapangan. Penting pula untuk melihat kreativitas dan kualitas guru-guru yang belum atau non-sertifikasi.

Penelitian ini sangat penting dilakukan, dan memiliki manfaat yang banyak. Manfaatnya secara teoritis dapat menjadi sarana pengembangan ilmu pengetahuan, dan sebagai bahan pertimbangan dalam upaya meningkatkan mutu dan kemajuan dunia

\footnotetext{
${ }^{5}$ Undang-Undang Republik Indonesia, hlm. 2.

${ }^{6}$ Ibid., hlm. 8.

${ }^{7}$ Riant Nugroho, Pendidikan Indonesia: Harapan ..., hlm. 28.
} 
pendidikan. Sedangkan manfaat praktis yang bisa didapatkan adalah menjadi koreksi dan bahan evaluasi bagi guru dan penyelanggara sertifikasi, untuk meningkatkan kualitas dan profesionalitas Sumber Daya Manusia (SDM) dalam pelaksanaan proses pendidikan dan pembelajaran.

\section{METODE PENELITIAN}

Penelitian ini tergolong penelitian kualitatif (qualitative research), sebuah penelitian yang ditujukan untuk mendeskripsikan dan menganalisis fenomena, peristiwa, aktivitas sosial, sikap, kepercayaan, persepsi, pemikiran orang secara individual maupun kelompok. Penelitian kualitatif ini mempunyai dua tujuan utama, pertama to describe and explore (untuk menggambarkan dan mengungkapkan), dan kedua describe and explain (menggambarkan dan menjelaskan). ${ }^{8}$

Populasi ${ }^{9}$ pada penelitian ini adalah seluruh guru SD Negeri Balirejo Yogyakarta yang berjumlah 9 orang, diantaranya ada 7 orang atau 77,7\% guru-guru telah sertifikasi, sedangkan sisanya 2 orang atau 22,2\% belum sertifikasi. Lokasi penelitian ini berlangsung di SD Negeri Balirejo terletak di Jl. Balirejo No. 28, Muja Muju, Kecamatan Umbul Harjo, Kota Yogyakarta. Penelitian ini dilakukan kurang lebih satu bulan, yaitu pada tanggal 06 Oktober sampai dengan 10 November 2015.

Sumber data pada penelitan ini, terdiri atas data primer dan data sekunder. Data primer yang peneliti gunakan adalah dokumen-dokumen yang telah dimiliki oleh SD Negeri Balirejo Yogyakarta, dapat pula berupa hasil observasi terhadap karakter fisik, kejadian, kegiatan, dan hasil pengujian tertentu. Opini dan tanggapan subjek secara individual dan kolektif ketika diwawancarai baik perannya sebagai Kepala Sekolah, Guru Sertifikasi dan Guru Non-Sertifikasi juga dijadikan sebagai data primer, begitu pula dengan hasil dokumentasi. Sedangkan data sekunder peneliti dapatkan dari pihak atau sumber lain yang mendukung, selain yang dari data primer.

Teknik pengumpulan data yang digunakan dalam penelitian ini adalah: Pertama, teknik observasi, yaitu teknik pengumpulan data dengan cara mengamati langsung setiap kejadian yang sedang berlangsung, dan mencatatnya dengan alat observasi tentang hal-hal yang akan diamati dan diteliti. ${ }^{10} \mathrm{Kedua}$, teknik wawancara, merupakan teknik pengumpulan data di mana pewawancara (peneliti atau yang diberi tugas melakukan pengumpulan data) dalam mengumpulan data mengajukan suatu pertanyaan kepada orang yang diwawancarai. ${ }^{11}$ Ketiga, teknik dokumentasi, yaitu pengumpulan data yang diperoleh melalui dokumen-dokumen. ${ }^{12}$ Dokumentasi penulis gunakan untuk mengetahui data pendidik (jumlah pendidik dan jenjang pendidikan para pendidik).

\footnotetext{
${ }^{8}$ Nana Syaodh Sukmadina, Metode Penelitian Pendidikan, (Bandung: Remaja Rosdakarya, 2008), hlm. 60.

${ }^{9}$ Populasi adalah keseluruhan objek penelitian. Apabila seseorang ingin meneliti semua elemen yang ada dalam wilayah penelitian maka penelitiannya merupakan penelitian populasi atau disebut juga sebagai penelitian sensus. Suharsimi Arikunto, dkk, Penelitian Tindakan Kelas, (Jakarta: Bumi Aksara, 2010), 115 .

${ }^{10}$ Wina Sanjaya, Penelitian Tindakan Kelas, (Jakarta: Kencana, 2009), hlm. 86.

${ }^{11}$ Sugiono, Metode Penelitian Kombinasi (mix Methods), (Bandung: Alfabeta, 2013), hlm. 188.

${ }^{12}$ Amirul Hadi, Metode Penelitian Pendidikan, (Bandung: Pustaka Setia, 2001), hlm. 111.
} 
Sedangkan teknik analisis data yang digunakan dalam penelitian ini adalah teknik deskriptif-analisis.

\section{HASIL DAN PEMBAHASAN}

\section{A. Sertifikasi dan Profesionalitas Guru}

\section{Sertifikasi Guru}

Undang-Undang Nomor 14 tahun 2005 tentang Guru dan Dosen pasal 1 butir 11 menyatakan bahwa, sertifikasi adalah proses pemberian sertifikat pendidik untuk guru dan dosen. Sedangkan pada butir 12 disebutkan bahwa, sertifikat pendidik adalah bukti formal sebagai pengakuan yang diberikan kepada guru dan dosen sebagai tenaga profesional. ${ }^{13}$ Martinis Yamin (2007) mendefinisikan sertifikasi sebagai "proses pemberian sertifikat pendidik untuk guru dan dosen atau bukti formal sebagai pengakuan yang diberikan kepada guru dan dosen sebagai tenaga profesional. ${ }^{14}$

Sedangkan Mulyasa (2013) menjelaskan, sertifikasi guru merupakan proses uji kompetensi bagi calon guru atau guru yang ingin memperoleh pengakuan dan atau meningkatkan kompetensi sesuai profesi yang dipilihnya. Representasi pemenuhan standar kompetensi yang telah ditetapkan dalam sertifikasi guru ialah sertifikat kompetensi pendidik. Sertifikat ini sebagai bukti pengakuan atas kompetensi guru atau calon guru yang memenuhi standar untuk melakukan pekerjaan profesi guru pada jenis dan jenjang pendidikan tertentu. ${ }^{15}$ Berdasarkan pengertian tersebut penulis menyimpulkan bahwa, sertifikasi guru dapat diartikan sebagai proses pemberian pengakuan atau legalitas terhadap seseorang yang telah memiliki kompetensi untuk melaksanakan pelayanan pendidikan pada satuan pendidikan tertentu, setelah ia lulus uji kompetensi yang diselenggarakan oleh lembaga sertifikasi dibuktikan dengan sertifikat pendidik yang diperolehnya.

Untuk menyelenggarakan sertifikasi guru, penyelenggara sertifikasi memiliki dan mematuhi prinsip-prinsip yang telah diterangkan dalam Pedoman Penetapan Peserta Sertifikasi. Pedoman ini disusun oleh pihak Departemen Pendidikan Nasional, prinsipprinsip tersebut sebagaimana yang dikutip Kunandar, yaitu:

a. Sertifikasi dilaksanakan secara objektif, transparan, dan akuntabel

Sertifikasi mesti berpedoman pada proses perolehan sertifikat pendidik, serta memenuhi standar pendidikan nasional, tanpa campur tangan subjektif dan intervensi pihak manapun. Transparansi berpedoman kepada proses sertifikasi yang memberikan peluang kepada para pemangku kepentingan pendidikan, untuk memperoleh akses informasi tentang proses dan hasil sertifikasi. Akuntabel merupakan proses sertifikasi yang dipertanggungjawabkan kepada pemangku kepentingan pendidikan secara administratif, finansial, dan akademik.

${ }^{13}$ Undang-Undang Republik Indonesia, Op.Cit., hlm. 4.

${ }^{14}$ Martinis Yamin, Sertifikasi Profesi Keguruan di Indonesia, (Jakarta: Gaung Persada, 2007), hlm. 2 .

${ }^{15}$ Ramdan, Dampak Positif Sertifikasi THD Kinerja Guru di SD Babakanmadang di Bogor, Skripsi UIN Syarif Hidayatullah, Jakarta, 2013, hlm. 25. 
b. Sertifikasi mesti berujung pada peningkatan mutu pendidikan nasional

Melalui peningkatan kesejahteraan guru sertifikasi disyaratkan pada peningkatan kompetensinya, menjadi tidak cukup sekedar bermodalkan kualifikasi akademik saja melainkan seorang guru memenuhi kompetensi kepribadian, akademik, profesional dan sosial. Sertifikasi guru merupakan upaya pemerintah, dalam meningkatkan mutu guru yang dibarengi dengan peningkatan kesejahteraan guru. Oleh karena itu, guru yang telah lulus uji sertifikasi akan diberi tunjangan profesi sebesar satu kali gaji pokok sebagai bentuk upaya pemerintah dalam meningkatkan kesejahteraan guru. Tunjangan tersebut berlaku, baik guru yang berstatus pegawai negeri sipil (PNS) maupun bagi guru yang berstatus bukan pegawai negeri sipil (swasta). Dengan peningkatan mutu dan kesejahteraan guru, maka diharapkan dapat meningkatkan mutu pembelajaran dan mutu pendidikan di Indonesia secara berkelanjutan.

c. Sertifikasi dilaksanakan sesuai dengan peraturan perundang-undangan

Program sertifikasi pendidik dilaksanakan dalam rangka memenuhi amanat Undang-undang Republik Indonesia Nomor 20 Tahun 2003 tentang Sistem Pendidikan Nasional, undang-undang Republik Indonesia Nomor 14 Tahun 2005 tentang Guru dan Dosen, dan Peraturan Pemerintah Nomor 19 Tahun 2005 tentang Standar Nasional Pendidikan. Perundang-undangan tersebut merupakan suatu ketetapan politik bahwa guru adalah pekerja profesional, yang berhak mendapatkan hak-hak sekaligus kewajiban profesional, sekaligus sebagai landasan hukum dan pelaksanaan sertifikasi agar tidak muncul berbagai penyimpangan dari aturan main yang sudah ada. Penyimpangan yang harus diwaspadai adalah, pelakasanaan sertifikasi yang tidak benar dan terdapat kecurangan. Oleh karenanya, begitu ada gejala penyimpangan, pemerintah harus mengambil tindakan tegas. Seperti mencabut hak melaksanakan sertifikasi dari lembaga yang dimaksud, atau menetapkan seseorang tidak boleh menjadi penguji sertifikasi dan lain sebagainya.

d. Sertifikasi dilaksanakan secara terencana dan sistematis

Agar pelaksanaan sertifikasi dapat berjalan dengan efektif dan efisien, maka harus direncanakan secara matang dan sistematis. Sertifikasi mengacu pada kompetensi guru dan standar kompetensi guru. Jumlah peserta sertifikasi guru ditetapkan oleh pemerintah. Untuk alasan efektifitas dan efisensi pelaksanaan sertifikasi guru serta penjaminan kualitas hasil sertifikasi, jumlah peserta pendidikan profesi dan uji kompetensi setiap tahun ditetapkan oleh pemerintah. Berdasarkan jumlah yang ditetapkan oleh pemerintah tersebut, maka disusunlah kuota guru peserta sertifikasi untuk masing-masing provinsi dan Kabupaten / Kota. Penyusunan dan penetapan kuota tersebut didasarkan atas jumlah data individu guru per-Kabupaten / Kota yang masuk di pusat data Direktorat Jenderal Peningkatan Mutu Pendidikan dan Tenaga Kependidikan.

e. Sertifikasi menghargai pengalaman guru

Pengalaman kerja guru di samping lamanya guru mengajar juga termasuk pendidikan dan pelatihan yang pernah diikuti, karya yang pernah dihasilkan baik dalam bentuk tulisan maupun media pembelajaran, serta aktivitas lain yang menunjang profesionalitas guru dalam mengajar. Dalam beberapa hal, guru yang mempunyai masa kerja lebih lama akan lebih berpengalaman dalam melakukan pembelajaran dibanding 
dengan guru yang masih relatif baru. Oleh karena itu, pengalaman kerja guru perlu mendapat penghargaan sebagai salah satu komponen yang diperhitungkan dalam sertifikat guru.

f. Sertifikasi mempertimbangkan jumlah peserta yang ditetapkan oleh pemerintah

Untuk alasan efektivitas dan efisiensi pelaksanaan sertifikasi guru serta penjaminan kualitas hasil sertifikasi, jumlah peserta pendidikan profesi dan uji kompetensi setiap tahunnya ditetapkan oleh pemerintah. Berdasarkan jumlah yang ditetapkan pemerintah tersebut, maka disusunlah kuota tersebut didasarkan atas jumlah data individu guru per Kabupaten / Kota yang masuk dipusat data Direktorat Peningkatan Mutu Pendidik dan Tenaga Kependidikan. ${ }^{16}$

Tujuan diadakannya sertifikasi guru secara umum adalah untuk meningkatkan kompetensi peserta, agar mencapai standar kompetensi yang telah ditentukan. Sedangkan secara khusus diadakannya program sertifikasi, dapat bertujuan untuk: meningkatkan kompetensi guru dalam bidang ilmunya; Menetapkan kemampuan mengajar guru; Mengembangkan kompetensi guru secara holistik sehingga mampu bertindak secara profesional; Meningkatkan kemampuan guru dalam kegiatan penelitian dan kegiatan ilmiah lain, serta memanfaatkan teknologi komunikasi informasi untuk kepentingan pembelajaran dan perluasan wawasan. ${ }^{17}$ Apabila tujuan-tujuan tersebut tercapai, meskipun dalam standar minimal, maka seorang guru sudah dapat disebut sebagai guru profesional.

Sertifikasi sangat memberikan banyak manfaat bagi guru-guru, seperti yang tercantum dalam Undang-undang No. 14, Tahun 2005. Manfaat-manfaat sertifikasi itu adalah:

a) Memperoleh penghasilan di atas kebutuhan hidup minimum dan jaminan kesejahteraan sosial.

b) Mendapat promosi dan penghargaan sesuai dengan tugas dan prestasi kerja.

c) Memperoleh perlindungan dalam melaksanakan tugas dan hak atas kekayaan intelektual.

d) Memperoleh kesempatan untuk meningkatkan kompetensi.

e) Memperoleh dan memanfaatkan sarana dan prasarana pembelajaran untuk menunjang kelancaran tugas keprofesionalannya.

f) Memiliki kebebasan dalam memberikan penilaian dan ikut menentukan kelulusan, penghargaan, dan/atau sanksi kepada peserta didik sesuai dengan kaidah pendidikan, kode etik guru, dan peraturan perundang-undangan.

g) Memperoleh rasa aman dan jaminan keselamatan dalam melaksanakan tugas.

h) Memiliki kebebasan untuk berserikat dalam organisasi profesi.

i) Memiliki kesempatan untuk mengembangkan dan meningkatkan kualifikasi akademik dan kompetensi. ${ }^{18}$

\footnotetext{
${ }^{16}$ Kunandar, Guru Profesional Implementasi Kurikulum Tingkat Satuan Pendidikan (KTSP), (Jakarta: PT. Raja Grafindo, 2007), hlm. 86.

${ }^{17}$ Depdiknas, Sertifikasi Guru dalam Jabatan, (Jakarta: Depdiknas, 2009), hlm. 3.

${ }^{18}$ Asrorun Ni'am Sholeh, Membangun profesionalisme Guru, Analisis Kronologis atas Lahirnya UU Guru dan Dosen, (Ciputat: eLSAS Jakarta, 2006), hlm. 163-164.
} 
Terkait dengan manfaat-manfaat yang diperoleh oleh guru sertifikasi di atas, Kunanadar berpendapat ada tiga manfaat penting yang dapat diperoleh oleh guru yang bersertifikasi, masyarakat, maupun lembaga penyelenggara tenaga kependidikan. Pertama, melindungi profesi guru dari praktik-praktik yang tidak kompeten, yang dapat merusak citra profesi guru. Kedua, melindungi masyarakat dari praktik-praktik pendidikan yang tidak berkualifikasi dan tidak profesional. Ketiga, menjaga lembaga penyelenggara tenaga kependidikan (LPTK) dari keinginan internal dan tekanan eksternal yang menyimpang dari ketentuan-ketentuan yang berlaku. ${ }^{19}$ Bila memperhatikan manfaat-manfaat yang telah didapatkan dan diperoleh oleh guru sertifikasi maka tentu kualitas dan mutu pendidikan sebagai output sertifikasi akan semakin meningkat lebih cepat. Masyarakat tidak perlu ragu dan mempertimbangkan kridibelitas guru sertifikasi yang mengajar di sekolah, sebab telah berada pada standar profesional.

\section{Profesionalitas Guru}

Profesionalitas merupakan kata sifat yang berasal dari kata profesion artinya sama dengan kata occupation, yaitu pekerjaan yang memerlukan keahlian yang diperoleh melalui pendidikan atau latihan khusus. ${ }^{20}$ Dalam pengertian lebih jauh, pekerjaan tersebut hanya dapat dilakukan oleh mereka yang khusus dipersiapkan untuk itu, bukan pekerjaan yang dilakukan oleh mereka yang tidak dapat memperoleh pekerjaan lain. ${ }^{21}$

Bila dikorelasikan dengan guru profesional, sesuai dengan Undang-undang Guru dan Dosen pasal 1 ayat 4, profesional adalah pekerjaan yang dilakukan oleh seseorang dan menjadi sumber penghasilan kehidupan yang memerlukan keahlian, kemahiran atau kecakapan yang memenuhi standar mutu atau norma tertentu serta memerlukan pendidikan profesi. ${ }^{22}$ Sementara itu, Ahmad Tafsir mendefinisikan, profesionalisme adalah paham yang mengajarkan bahwa setiap pekerjaan harus dilaksanakan oleh orang yang profesional. ${ }^{23}$

Dari beberapa definisi dan penjelasan di atas, dapat ditarik benang merah bahwa yang dimaksud Profesionalitas Guru adalah sebutan yang mengacu pada sifat dan sikap seorang guru yang memiliki keahlian, kemahiran, dan kecakapan yang memenuhi standar atau norma tertentu. Karena memiliki keahlian, kemahiran, dan kecakapan yang telah diperoleh dari proses pendidikan dan pelatihan, maka profesi atau pekerjaan seorang guru berhak mendapatkan gaji sebagai sumber penghasilan untuk memenuhi kebutuhan hidupnya.

\footnotetext{
${ }^{19}$ Kunandar, Guru Profesional Implementasi, hlm. 79.

${ }^{20}$ Muhammad Arifin, Kapita Selekta Pendidikan, (Jakarta: Bumi Aksara, 1996), hlm. 105

${ }^{21}$ Moeh Uzer Usman, Menjadi Guru Profesional, (Bandung: PT. Remaja Rosdakarya, 1995), hlm. 14 .

${ }^{22}$ Undang-undang Republik Indonesia, hlm. 3.

${ }^{23}$ Ahmad Tafsir, Ilmu Pendidikan dalam presfektif Islam, (Bandung: Rosdakarya, 1994), hlm. 107.
} 
Untuk mewujudkan sikap profesional guru, maka diaturlah ketentuan dalam Undang-undang No. 14 Tahun 2005 tentang Guru dan Dosen, pada Pasal 8 menyebutkan bahwa guru wajib memiliki kualifikasi akademik, kompetensi, sertifikat pendidik, sehat jasmani dan rohani, serta memiliki kemampuan untuk mewujudkan tujuan pendidikan nasional. Selanjutnya pada pasal 9 Undang-undang Guru dan Dosen No. 14 Tahun 2005, menyatakan bahwa kualifikasi akademik sebagaimana dimaksud dalam Pasal 8 diperoleh melalui pendidikan tinggi program sarjana atau program Diploma Empat. $^{24}$

Berkenaan dengan ini dapat dikatakan bahwa guru profesional adalah orang yang memiliki kemampuan dan keahlian khusus dalam bidang keguruan, sehingga ia mampu melakukan tugas dan fungsinya sebagai guru dengan kemampuan maksimal. Pendefinisian ini sejalan dengan Peraturan Pemerintah Nomor 29 tahun 2005 tentang Standar Nasional Pendidikan pasal $25^{25}$ dan Undang-undang Nomor 14 Tahun 2005. Kompetensi guru dalam sertifikasi terdapat dalam Undang-Undang Guru dan Dosen Nomor 14 Tahun 2005 Pasal 10 yang berbunyi kompetensi guru sebagaimana dimaksud dalam Pasal 8 meliputi kompetensi pedagogik, kompetensi kepribadian, kompetensi sosial, dan kompetensi profesional yang diperoleh melalui pendidikan profesi. ${ }^{26}$

a. Kompetensi Pedagogik

Kompetensi pedagogik adalah pemahaman guru terhadap anak didik, perencanaan, pelaksanaan pembelajaran, evaluasi hasil belajar, dan pengembangan anak didik untuk mengaktualisasikan sebagai kompetensi yang dimilikinya. Kompetensi pedagogik ini juga sering dimaknai sebagai kemampuan mengelola pembelajaran, yang mana mencakup tentang konsep kesiapan mengajar, yang ditunjukkan oleh penguasaan pengetahuan dan keterampilan mengajar. ${ }^{27}$ Sesuai Peraturan Menteri Pendidikan tahun 2005, ada sepuluh standar kompetansi pedagogik, yaitu:

1) Menguasai karakteristik peserta didik dari aspek fisik, moral, spiritual, sosial, kultural, emosional, dan intelektual.

2) Menguasai teori belajar dan prinsip-prinsip pembelajaran yang mendidik.

3) Mengembangkan kurikulum yang terkait dengan mata pelajaran yang diampu.

4) Menyelenggarakan pembelajaran yang mendidik.

5) Memanfaatkan teknologi informasi dan komunikasi untuk kepentingan pembelajaran.

6) Memfasilitasi pengembangan potensi peserta didik untuk mengaktualisasikan berbagai potensi yang dimiliki.

7) Berkomunikasi secara efektif, empatik, dan santun dengan peserta didik.

8) Menyelenggarakan penilaian dan evaluasi proses dan hasil belajar.

9) Memanfaatkan hasil penilaian dan evaluasi untuk kepentingan pembelajaran.

${ }^{24}$ Undang-Undang Republik Indonesia, hlm. 6.

${ }^{25}$ Anonim, Kumpulan Undang-Undang dan Peraturan Pemerintah Republik Indonesia, (Jakarta: Asa Mandiri, 2008), hlm. 196.

${ }^{26}$ Undang-Undang Republik Indonesia, hlm. 6.

${ }^{27}$ Agus Wibowo dan Hamrin, Menjadi Guru Berkarakter, (Yogyakarta: Pustaka Pelajar, 2012), hlm. 110 . 
10) Melakukan tindakan reflektif untuk peningkatan kualitas pembelajaran. ${ }^{28}$

b. Kompetensi Kepribadian

Kompetensi kepribadian adalah kemampuan personal yang mencerminkan kepribadian yang mantap, stabil, dewasa, arif dan berwibawa, menjadi teladan bagi peserta didik, dan berakhlak mulia. Standar yang harus dipenuhi dalam kompetensi kepribadian ini meliputi:

1) Bertindak sesuai dengan norma agama, hukum, sosial, dan kebudayaan nasional Indonesia.

2) Menampilkan diri sebagai pribadi yang jujur, berakhlak mulia, dan teladan bagi peserta didik dan masyarakat.

3) Menampilkan diri sebagai pribadi yang mantap, stabil, dewasa, arif, dan berwibawa.

4) Menunjukkan etos kerja, tanggung jawab yang tinggi, rasa bangga menjadi guru, dan rasa percaya diri.

5) Menjunjung tinggi kode etik profesi guru. ${ }^{29}$

c. Kompetensi Sosial

Kompetensi sosial adalah kemampuan guru dalam berkomunikasi dan berinteraksi secara efektif dengan lingkungan sekolah maupun di luar lingkungan sekolah. ${ }^{30}$ Ada empat standar kompetensi sosial berdasarkan ini adalah:

1) Bersikap inklusif, bertindak objektif, serta tidak diskriminatif karena pertimbangan jenis kelamin, agama, ras, kondisi fisik, latar belakang keluarga, dan status sosial ekonomi.

2) Berkomunikasi secara efektif, empatik, dan santun dengan sesama pendidik, tenaga kependidikan, orangtua, dan masyarakat.

3) Beradaptasi di tempat bertugas diseluruh wilayah Republik Indonesia yang memiliki keragaman sosial budaya.

4) Berkomunikasi dengan komunitas profesi sendiri dan profesi lain secara lisan dan tulisan atau bentuk lain. ${ }^{31}$

\section{d. Kompetensi Profesional}

Kompetensi profesional adalah berbagai kemampuan yang diperlukan agar dapat mewujudkan dirinya sebagai guru profesional. Kompetensi profesional meliputi kepakaran atau keahlian dalam bidangnya, yaitu penguasaan bahan yang harus diajarkannya beserta metodenya, rasa tanggung jawab akan tugasnya dan rasa kebersamaan dengan sejawat guru lainnya. ${ }^{32}$

Guru dituntut mencari tahu bagaimana seharusnya peserta didiknya belajar. Apabila ada kegagalan yang dialami oleh peserta didik, maka guru terpanggil untuk menemukan penyebabnya dan mencari jalan keluar bersama peserta didik bukan

13.

${ }^{28}$ Peraturan Menteri Pendidikan Nasional Republik Indonesia, Nomor 16 Tahun 2007, hlm. 11-

${ }^{29}$ Ibid., hlm. 13-14.

${ }^{30}$ Agus Wibowo dan Hamrin, Menjadi Guru Berkarakter, hlm.124.

${ }^{31}$ Peraturan Menteri Pendidikan, hlm. 14-15.

${ }^{32}$ Piet. A. Sohertian, Profil Pendidik Profesional, (Yogyakarta: Andi Ofseet, 1994), hlm. 30. 
mendiamkannya atau malahan menyalahkannya. Sikap yang harus senantiasa dipupuk adalah kesediaan untuk mengenal diri dan kehendak untuk memurnikan keguruannya. Mau belajar dengan meluangkan waktu untuk menjadi guru. Seorang guru yang tidak bersedia belajar, tidak akan mungkin betah dan bangga menjadi guru. Betah dan bangga atas keguruannya adalah langkah untuk menjadi guru yang berkompetensi profesional. ${ }^{33}$ Ada lima standar kompetensi profesional, yaitu:

1) Menguasai materi, struktur, konsep, dan pola pikir keilmuan yang mendukung mata pelajaran yang diampu.

2) Menguasai standar kompetensi dan kompetensi dasar mata pelajaran yang diampu.

3) Mengembangkan materi pembelajaran yang diampu secara kreatif.

4) Mengembangkan keprofesionalan secara berkelanjutan dengan melakukan tindakan reflektif.

5) Memanfaatkan teknologi informasi dan komunikasi untuk mengembangkan diri. $^{34}$

\section{Ciri-ciri Kompetensi Guru yang Baik}

Pada dasarnya tugas guru yang paling utama adalah mengajar dan mendidik. Sebagai pengajar ia merupakan medium atau perantara aktif antara siswa dan ilmu pengetahuan, sedangkan sebagai pendidik ia merupakan medium aktif antara siswa, haluan Negara, dan kehidupan masyarakat dengan segala seginya. Menjadi medium untuk mengembangkan pribadi siswa serta mendekatkan mereka dengan pengaruhpengaruh dari luar yang baik dan menjauhkan mereka dari pengaruh-pengaruh yang buruk. Dengan demikian seorang guru wajib memiliki segala sesuatu yang erat hubungannya dengan bidang tugasnya, yaitu pengetahuan, kepribadian, serta kesehatan jasmani dan rohani.

Sebagai teladan, guru harus memahami hakikat mengajar dan mengetahui teoriteori mengajar serta dapat menerapkannya. Dengan mengetahui dan mendalaminya ia akan lebih berhati-hati dalam menjalankan tugasnya, dapat memperbaiki kekurangankekurangan yang telah dilakukannya. Menurut S. Nasution (2009) ada beberapa prinsip umum yang berlaku untuk semua guru yang baik, yaitu:

a. Guru yang baik memahami dan menghormati siswa. Guru yang baik harus menghormati bahan pelajaran yang diberikan. Dengan pengertian, ia harus menguasai bahan itu sepenuhnya, jangan hanya mengenal ini buku pelajaran saja, melainkan juga mengetahui pemakaian dan kegunaannya bagi kehidupan anak dan manusia umumnya.

b. Guru yang baik mampu menyesuaikan metode mengajar dengan bahan pelajaran.

c. Guru yang baik mampu menyesuaikan bahan pelajaran dengan kesanggupan individu anak.

d. Guru yang baik harus mengaktifkan siswa dalam hal belajar.

${ }^{33}$ Kunandar, Guru Profesional Implementasi, (Jakarta : Rajawali Press), 2010, hal 48-49

${ }^{34}$ Peraturan Menteri Pendidikan, hlm. 14-15. 
e. Guru yang baik memberikan pengertian dan bukan hanya dengan kata-kata belaka. Dengan pengertian lain guru tidak bersifat verbalistis, yakni hanya mengenalkan anak terhadap kata-kata saja, tetapi tidak dapat menyelami arti maksudnya.

f. Guru menghubungkan pelajaran dengan kebutuhan siswa.

g. Guru merumuskan tujuan yang akan dicapai, pada setiap pelajaran yang diberikannya.

h. Guru jangan hanya terikat oleh satu teks book saja.

i. Guru yang baik tidak hanya mengajar dalam arti menyampaikan pengetahuan saja kepada siswa, melainkan senantiasa membentuk pribadi siswa. ${ }^{35}$

Tidak menutup kemungkinan terdapat ciri-ciri lain yang dapat menjadi indikator sebagai guru yang baik. Tetapi paling tidak, ciri-ciri ini dapat dipedomani oleh setiap guru yang akan menjalankan tugasnya, baik sebagai pendidik maupun sebagai pengajar.

Guru yang baik akan selalu bersikap obyektif, terbuka untuk menerima kritik terhadap kelemahan-kelemahan yang ada pada dirinya, misalnya bagaimana caranya mengajar. Ini diperlukan dalam upaya perbaikan mutu pendidikan dan demi kepentingan anak didik, sehingga tujuan pendidikan dapat tercapai dengan baik. Keberanian melihat kesalahan sendiri dan mengakuinya tanpa mencari alasan, untuk membenarkan atau mempertahankan diri dengan sikap defensif adalah salah satu titik tolak kearah usaha perbaikan itu.

\section{B. Realitas Guru-guru di SD Negeri Balirejo Yogyakarta}

\section{Kompetensi Guru-guru Sertifikasi SD Negeri Balirejo Yogyakarta}

Empat kompetensi profesionalitas guru yang telah diulas sebelumnya, penulis gunakan sebagai indikator penilaian ketika melakukan penelitian terhadap guru-guru sertifikasi di SD Negeri Balirejo Yogyakarta. Hasil observasi, wawancara, dan dokumentasi terhadap 7 orang guru sertifikasi SD Negeri Balirejo Yogyakarta, peneliti memperoleh hasil sebagai berikut:

\section{a. Kompetensi Pedagogik}

Pertama, mayoritas guru-guru bersertifikasi di SD Negeri Balirejo Yogyakarta masih menggunakan pendekatan pembelajaran klasikal yang telah mapan yaitu teacher centered, alasan mereka menggunakan pendekatan tersebut karena lebih efektif, ditambah lagi faktor siswa dan sarana prasarana SD Negeri Balirejo yang belum mendukung. Kedua, guru-guru sertifikasi tidak melakukan pengembangan pendekatan pembelajaran yang bervariasi, alasannya karena siswa-siswa dianggap sudah cukup memahami materi yang diajarkan. Ketiga, guru-guru sertifikasi SD Negeri Balirejo tidak memanfaatkan ICT (Information and Communications Technology) secara maksimal, alasan utama mereka tidak memanfaatkan ICT yang ada di sekolah tersebut adalah karena tidak ingin timbul kesan mempersulit dan memonopoli siswa maupun wali siswa.

${ }^{35}$ S. Nasution, Dedaktik Asas-asas Mengajar, (Bandung: Jemmars, 2009), hlm. 12 - 17. 
b. Kompetensi Kepribadian

Pertama, guru-guru sertifikasi SD Negeri Balirejo Yogyakarta telah bertindak sesuai dengan norma agama, hukum, sosial dan kebudayaan nasional Indonesia secara baik. Kedua, guru-guru SD Negeri Balirejo telah menjunjung tinggi akhlak mulia, menerapkan dan berprilaku sesuai dengan kode etik profesi guru. Ketiga, meski belum maksimal guru-guru telah menunjukkan etos kerja, bertanggung jawab, percaya diri, dan bangga dengan profesi keguruannya, padahal SD Negeri Balirejo Yogyakarta dapat dikatakan sebagai sekolah terbelakang atau kurang peminat.

\section{c. Kompetensi sosial}

Pertama, Guru-guru sertifikasi SD Negeri Balirejo Yogyakarta telah mempu bersikap inklusif dan objektif, serta tidak diskriminatif dengan membedakan jenis kelamin, agama, ras, kondisi fisik, latar belakang keluarga, dan status sosial ekonomi. Kedua, guru-guru dapat berkomunikasi secara efektif, empatik, dan santun dengan sesama pendidik, tenaga kependidikan, orangtua siswa, dan masyarakat. Ketiga, guruguru sertifikasi SD Negeri Balirejo telah mampu beradaptasi di lingkungan tempat mereka bertugas dengan sesama guru maupun dengan tenaga kependidikan di sekolah.

\section{d. Kompetensi Profesional}

Pertama, Guru-guru sertifikasi SD Negeri Balirejo Yogyakarta secara umum telah memenuhi tuntutan aspek kompetensi dalam menguasai materi, struktur, konsep dan pola pikir keilmuan yang mendukung mata pelajaran yang diampu. Kedua, Guruguru sertifikasi mampu mengembangkan materi pembelajaran yang diampu secara kreatif. Ketiga, Guru-guru sertifikasi hanya sebagian kecil saja yang menggunakan dan Memanfaatkan teknologi informasi dan komunikasi (ICT), untuk mengembangkan diri. Fakta ini peneliti amati saat datang ke sekolah untuk melakukan observasi ketika di luar kelas maupun di dalam kelas. Peneliti juga menyaksikan masih banyak guru sertifikasi yang minta dibuatkan silabus, RPP dan penilaian kepada operator ataupun guru lain.

Berdasarkan hasil observasi dan wawancara di atas, kompetensi guru-guru sertifikasi di SD Negeri Balirejo masih belum maksimal dan dapat dikatakan belum profesional. Sehingga peneliti merasa perlu untuk memberikan saran agar mutu dan kualitas guru lebih meningkat, paling tidak mencapai standar yang telah ditargetkan oleh Kementerian Pendidikan Nasional. Saran-saran tersebut adalah sebagai berikut: 1). Reinforcement, diperlukan penguatan kepada poin-poin yang rendah dalam aspek kompetensi guru. 2). Reorientasi tujuan, guru perlu memperbaharui tujuan mengikuti sertifikasi, bahwa memburu kesejahteraan bukan tujuan utama, tetapi perlu mengutamakan peningkatan proses dan hasil pendidikan. 3). Monitoring dan Evaluasi, diperlukan monitoring dan evaluasi terhadap guru sertifikasi dari pihak yang berwenang. Dan semestinya diberi kategori penilaian, misalnya jika tidak mencapai $75 \%$, maka tunjangan sertifikasi di-stop. 4). Self control dan self correction, diperlukan semacam kesadaran pada tiap individu, baik implementator maupun kelompok sasaran untuk memperbaharui preferensi nilai yang dimiliki (karakter). 5). Control social, diperlukan control social dari masyarakat untuk pengendali dan self balancing agar tidak terjadi penyelewengan terhadap hakikat sertifikasi. 6) Berikan konstribusi, semua 
pihak diharapkan agar dapat memberikan konstribusi positif terhadap program sertifikasi.

\section{Kompetensi Guru-guru Non-Sertifikasi SD Negeri Balirejo Yogyakarta}

Terhadap guru non-sertifikasi yang berjumlah 2 orang, penulis melakukan observasi sebanyak 3 kali pertemuan yaitu pada tanggal 18, 21 dan 24 November 2015. Setelah beberapa kali melakukan observasi tersebut diperoleh hasil sebagai berikut:

a. Ketika proses pembelajaran berlangsung, dapat diketahui bahwa guru nonsertifikasi telah menguasai teori belajar dan prinsip-prinsip pembelajaran yang mendidik. Selain itu pendekatan pembelajaran yang digunakan tidak tertumpu pada teacher Centered, namun juga pendekatan kausal (arah timbal balik). Selain itu, guru juga mengembangkan materi pembelajaran yang diampu secara kreatif, dengan cara mengaitkan materi dengan realita.

b. Dalam proses pembelajaran telah menggunakan metode yang bervariasi, tidak hanya ceramah saja, tapi kombinasi antara ceramah, tanya jawab dan exsperimen (praktek). Contohnya ketika materi Perubahan Wujud Benda. Guru meminta siswa membawa (kantong plastik, rantang, panci besar, air, garam dapur, bongkahan es. Guru mempraktekkan dan diikuti oleh siswa.

c. Bahan ajarnya lengkap, baik buku paket, LKS dan RPP.

d. Ketika proses belajar mengajar, terutama ketika membahas soal latihan atau pekerjaan rumah (PR), ada hal-hal yang patut untuk dicontoh, yaitu: (a) Ada seorang anak yang tertinggal LKS, guru non-sertifikasi tersebut meminta anak yang ketinggalan LKS untuk membuka buku paket dan memintanya mengerjakan soalsoal objektif. (b) Teknik dalam mengoreksi latihan dengan menukar LKS dengan teman sebelah. (c) Sebelum memberikan kunci jawaban, guru terlebih dahulu meminta siswa untuk menjawab, sampai beberapa siswa yang angkat tangan dan menjawab, jika sudah sekitar 4-5 orang tidak ada jawaban yang tepat, baru guru memberi jawaban. (d) Ketika mengambil nilai, guru memanggil nama sesuai urutan absen. (e) Guru menegur dan memberi perhatian kepada siswa yang nilainya rendah, kenapa nilainya rendah?”. Kemudian guru tersebut memberi penguatan dengan ucapan "eman-eman, teman yang lain bisa dapat nilai yang tinggi, kenapa yang lain nilainya rendah".

Berdasarkan hasil observasi terhadap guru-guru non-sertifikasi di SD Negeri Balirejo Yogyakarta tersebut, dapat ditarik kesimpulan bahwa proses pembelajaran berlangsung sangat baik bahkan lebih baik dibandingkan dengan guru-guru sertifikasi. Guru non-sertifikasi, telah memenuhi standar kompetensi guru yang meliputi: kompetensi pedagogik, kompetensi kepribadian, kompetensi sosial, dan kompetensi profesional. Namun yang masih kurang mendukung adalah dari sisi sarana dan prasarana. Jumlah siswa terlalu banyak (over capacity), sedangkan kelasnya sempit sehingga suasana kurang kondusif. Karena penyediaan sarana dan pra-sarana belum memadai, peneliti menyarankan agar ada dua guru dalam satu kelas khusus untuk kelas IV. Seorang guru khusus mengajarkan materi, dan yang seorang lagi mengkondisikan siswa agar tidak rebut. Sehingga suasanya kelas akan lebih terkontrol dan nyaman. 


\section{KESIMPULAN DAN SARAN}

Berdasarkan observasi, wawancara, dan dokumentasi terhadap guru-guru sertifikasi SD Negeri Balirejo Yogyakarta masih banyak yang belum tuntas mencapai standar kompetensi pendidikan nasional, sehingga legalitas sertifikasi yang dimilikinya tidak dapat menunjukkan bahwa guru-guru yang bersangkutan telah dianggap sebagai guru profesional. Dengan kata lain, keprofesionalan seorang guru tidak dapat diukur melalui sertifikasi, kecuali telah disesuaikan kompetensi ketika memberikan pembelajaran. Penelitian ini juga membuktikan bahwa di lapangan terdapat guru-guru yang non-sertifikasi namun telah memenuhi standar kompetensi, sehingga sudah dapat dikatakan sebagai guru yang ideal dan profesional. Untuk meminimalisir dan menyelesaikan persoalan kesenjangan antara legalitas sertifikasi dengan realitas di lapangan, peneliti mengajukan beberapa saran untuk melakukan reinforcement, meorientasi tujuan, monitoring dan evaluasi, mengadakan self kontrol dan self correction, melaksanakan kontrol social, dan adanya konstribusi dari berbagai pihak terkait.

\section{UCAPAN TERIMAKASIH}

Penulis mengucapkan terima kasih kepada keluarga besar SD Negeri Balirejo Yogyakarta tempat penulis meneliti, terutama kepada Kepala Sekolah, Guru-guru sertifikasi, dan guru-guru non-sertifikasi yang telah memberikan izin untuk mengadakan penelitian dan berkenan untuk diobservasi, diwawancarai, dan didokumentasikan dalam tulisan ini.

\section{DAFTAR PUSTAKA}

Anonim. 2008. Kumpulan Undang-Undang dan Peraturan Pemerintah Republik Indonesia. Jakarta: Asa Mandiri.

Arifin, Muhammad. 1996. Kapita Selekta Pendidikan. Jakarta: Bumi Aksara.

Arikunto, Suharsimi dkk. 2010. Penelitian Tindakan Kelas. Jakarta: Bumi Aksara.

Depdiknas. 2009. Sertifikasi Guru dalam Jabatan. Jakarta: Depdiknas.

Hadi, Amirul. 2001. Metode Penelitian Pendidikan. Bandung: Pustaka Setia.

Kunandar. 2007. Guru Profesional Implementasi Kurikulum Tingkat Satuan Pendidikan (KTSP). Jakarta: PT. Raja Grafindo.

Muhaimin, Yahya. 2002. Reformasi Pendidikan dalam Konteks Otonomi Daerah, Faisal Jalal dan Dede Supriadi (ed.) Yogyakarta: Depdiknas, Bapenas dan Adicita Karya Nusa.

Nasution, S. 2009. Dedaktik Asas-asas Mengajar. Bandung: Jemmars.

Nugroho, Riant. 2008. Pendidikan Indonesia: Harapan, visi dan strategi. Yogyakarta: Pustaka Pelajar.

Peraturan Menteri Pendidikan Nasional Republik Indonesia. Nomor 16 Tahun 2007.

Ramdan. 2013. Dampak Positif Sertifikasi THD Kinerja Guru di SD Babakanmadang di Bogor, Skripsi UIN Syarif Hidayatullah, Jakarta.

Sanjaya, Wina. 2009. Penelitian Tindakan Kelas. Jakarta: Kencana.

Sholeh, Asrorun Ni'am. 2006. Membangun profesionalisme Guru, Analisis Kronologis atas Lahirnya UU Guru dan Dosen. Ciputat: eLSAS Jakarta.

Sohertian, Piet. A. 1994. Profil Pendidik Profesional. Yogyakarta: Andi Ofseet.

Sugiono, 2013. Metode Penelitian Kombinasi (mix Methods). Bandung: Alfabeta. 
Sukmadina, Nana Syaodh. 2008. Metode Penelitian Pendidikan. Bandung: Remaja Rosdakarya.

Tafsir, Ahmad. 1994. Ilmu Pendidikan dalam presfektif Islam. Bandung: Rosdakarya, 1994.

Undang-undang Republik Indonesia Nomor 14 tahun 2005.

Usman, Moeh Uzer. 1995. Menjadi Guru Profesional. Bandung: PT. Remaja Rosdakarya.

Wibowo, Agus. dan Hamrin. 2012. Menjadi Guru Berkarakter: Strategi Membangun Kompetensi dan Karakter Guru. Yogyakarta: Pustaka Pelajar.

Yamin, Martinis. 2007. Sertifikasi Profesi Keguruan di Indonesia. Jakarta: Gaung Persada. 